\title{
Ojal de prepucio con fines sexuales
}

\author{
López Luque A, Horques Pérez JA, Verdú Martínez M.
}

Hospital General Santa Ana de Motril. Granada.

Actas Urol Esp. 2008;32(5):571

$\mathrm{V}$ arón de 19 años en el que visualizamos durante la intervención quirúrgica de un varicocele izquierdo la existencia de un ojal prepucial realizado artificialmente en la cara dorsal del pene. Cuando preguntamos al paciente la finalidad de dicha plastia prepucial nos comenta que fue realizada en su país de origen (Marruecos) con la finalidad de colocar en el mismo objetos que mejoren la calidad de sus relaciones sexuales.

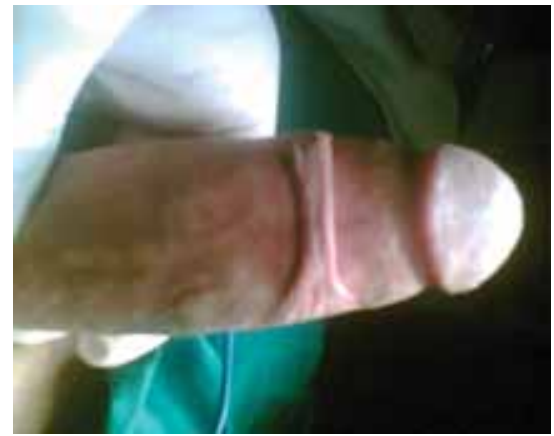

FIGURA 1

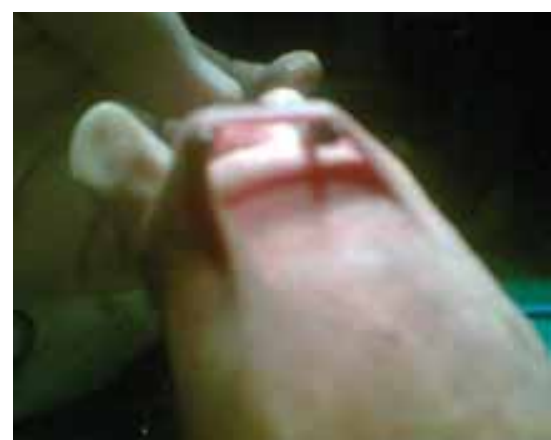

FIGURA 2

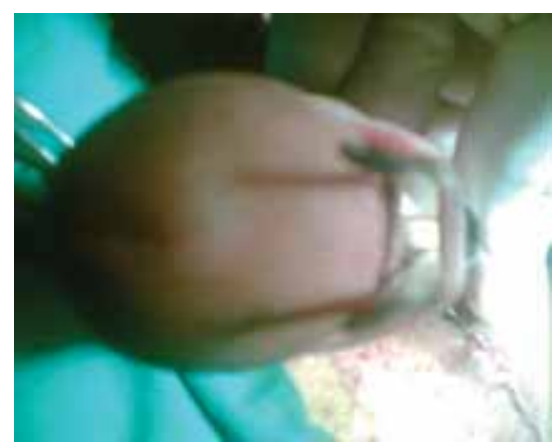

FIGURA 3

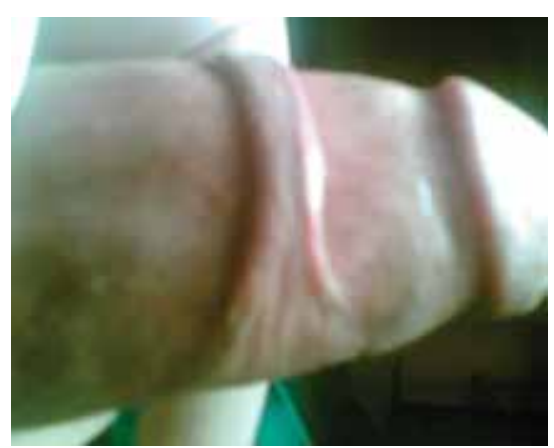

FIGURA 4

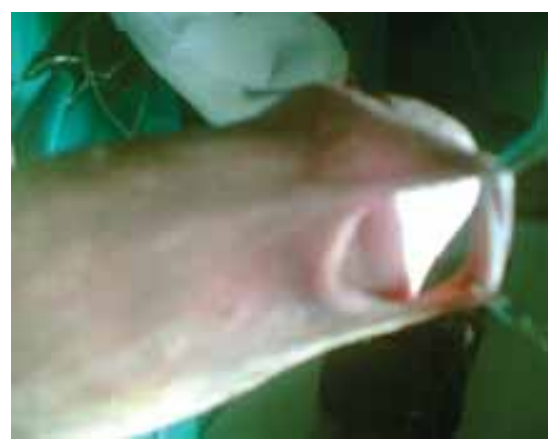

FIGURA 5

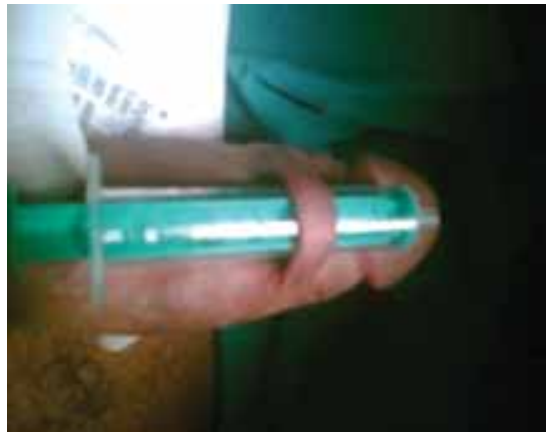

FIGURA 6

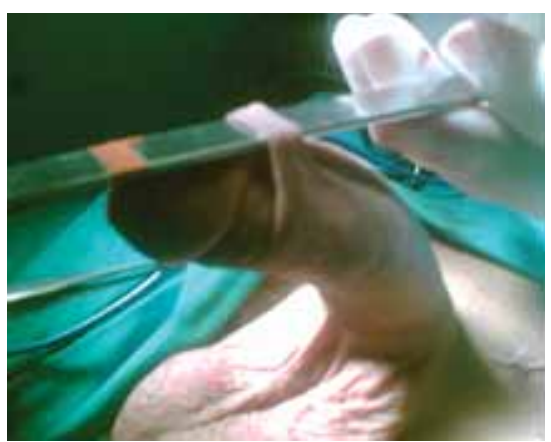

FIGURA 7

Correspondencia autor: Dr. A. López Luque Servicio de Urología

Hospital General Sta. Ana de Motril

Avda. Enrique Martín Cuevas, s/n

18600 Motril (Granada)

Tel.: 958038200

E-mail autor: allo2198@hotmail.com

Información artículo: Imágenes en urología

Trabajo recibido: diciembre 2006

Trabajo aceptado: enero 2007 